\title{
Are Banks And Stock Markets Positively Related? Empirical Evidence From South Africa
}

Nicholas M Odhiambo, University of South Africa, South Africa

\begin{abstract}
In this study, we examine the relationship between banks and stock market development in South Africa. The study attempts to answer one critical question: Are banks and stock markets positively related in South Africa? The bank development is proxied by the ratio of the domestic credit to the private sector to GDP (DCP/GDP), while the stock market development is proxied by the ratio of the stock market capitalisation to GDP (CAP/GDP).Unlike the majority of the previous studies, the current study uses the newly introduced ARDL-Bounds testing approach, as proposed by Pesaran et al. (2001), to examine this linkage. The empirical results show that there is a distinct positive relationship between banks and stock markets in South Africa. The results apply irrespective of whether the model is estimated in the short run or in the long run. Other results show that in the short run, the stock market development in South Africa is positively determined by the level of savings, but negatively affected by the rate of inflation and the lagged values of the stock market development. However, in the long run, the stock market is positively determined by real income and the inflation rate.
\end{abstract}

Keywords: South Africa, Stock Market Development, Banks, ARDL-Bounds Testing Approach

\section{INTRODUCTION}

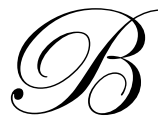

roadly speaking, financial systems can be divided into bank-based and market-based types, according to the relative roles of financial institutions and financial markets. Whether the economic growth is largely influenced by the development in the banking sector or by the financial markets sector is, however, a question that is currently being debated. This debate has been fuelled by the differing economic developments in countries that first concentrated on financial markets, like the United Kingdom (UK) and the United States of America (USA), and those that gave priority to the system of universal banks (e.g. Germany and Japan, etc. $)^{1}$. The current mainstream view, however, is that countries contemplating developing a highly sophisticated bank-based financial system should also develop a modest capital market that can complement the bank-based financial system ${ }^{2}$.

Unfortunately, the dynamic relationship between bank-based financial development and stock market development has not been fully explored in many developing countries. Previous studies have mainly concentrated on the relationship between bank-based financial development and economic growth, or on the stock market development and economic growth. In addition, these studies have been concentrated mainly on Asian countries and Latin America, leaving many African countries with little or no coverage at all. Moreover, the majority of these studies suffer from two major weaknesses. Firstly, these studies have mainly used either the residual-based cointegration test, associated with Engle and Granger (1987), or the maximum-likelihood test based on Johansen (1988) and Johansen and Juselius (1990). These tests may not be appropriate when the sample size is too small (see Nerayan and Smyth, 2005). Secondly, some of these studies have over-relied on the cross-sectional data, which may

\footnotetext{
${ }^{1}$ See Lee (2001).

${ }^{2}$ For more details, see Lee (2001).
} 
not satisfactorily address the country-specific issues. The current study, therefore, attempts to fill this lacuna by examining the dynamic relationship between bank-based financial development and stock market development using the newly introduced ARDL-Bounds testing approach proposed by Pesaran et al. (2001). Specifically, the study attempts to answer one critical question: Are stock markets and banks positively related in South Africa?

The rest of the paper is organized as follows: Section 2 gives a detailed outline of the financial sector development in South Africa. Section 3 deals with the theoretical and empirical literature review, while section 4 deals with the empirical model specification, the estimation techniques, and the empirical analysis of the regression results. Section 5 concludes the study.

\section{FINANCIAL SECTOR DEVELOPMENT IN SOUTH AFRICA}

\section{Banking Sector Development}

The origin of commercial banking in South Africa is linked to the first Currency and Banking Act (Act, No. 31 of 1920), which defined banks as companies receiving or accepting deposits of money, subject to withdrawal by cheque, draft or order. In 1942, another Act was passed - the Banking Act of 1942. This Act gave banks a broader definition. It classified banks into four kinds of institutions, namely a commercial bank, a people's bank, a loan bank and a deposit-receiving institution. However, in 1965 all classes of banking institutions, except discount houses, were subjected to the same financial requirements under the Bank Act, No. 23 of 1965. During the 1970s, the rapid development and diversification of the services offered by banks made the classification of banking institutions more complicated. From the 1980s, the distinction between the various classes of financial institutions faded considerably in South Africa due to the amalgamations and takeovers involving banks and building societies. In 1991, building societies, commercial banks, discount houses, general banks and merchant banks were grouped together to form banking institutions.

During the 1960s and 1980s, the private banking activities in South Africa were restricted by the extensive use of direct monetary control instruments. Credit ceilings were increasingly implemented by the Reserve Bank - in an attempt to curtail over-borrowing and to dampen inflation._However, after the implementation of the De Kock Commission recommendations, South African banks were faced with increasing adherence to free market principles by the monetary authorities. This led to large-scale deregulation and rationalisation - which resulted in a reduction in the banks' previously high cash-reserves and liquid-asset requirements. However, in 1985 the cash reserve requirement was subsequently increased in order to tighten liquidity and to restrain the high level of credit extension. Although for many years it was the policy of the South African authorities to ban the entry of new foreign banks into the country, this policy was reversed during the financial liberalisation era by the Deposit-Taking Institutions Act of 1990. During this period, the shareholding restrictions on foreign banks operating in South Africa were removed. In addition, other restrictions on the entry of new foreign banks were also lifted (see Falkena et al., 1995; SA Financial Sector Forum).

By the standards of developing countries, South Africa is considered to have one of the most developed and sophisticated banking systems. By 1997, South Africa had about 51 licensed banks and five mutual (community) banks. Out of the 51 licensed banks, eight were branches of foreign banks, whilst 11 were subsidiaries of foreign banks. Today there are about 60 banks in South Africa, including 13 branches of foreign banks and four mutual banks. Although South Africa is currently considered to have one of the most developed and sophisticated financial systems in sub-Saharan Africa, its market share is still dominated by only a few financial institutions. By the mid1990 s, for example, more than $95 \%$ of banks' total assets were held by only four banking groups, while the remaining 5\% were spread among 27 local banks, nine foreign-controlled banks, and a few branches of foreign banks, as well as some mutual banks. Also, the financial depth (measured by M2/GDP) has not increased significantly since the implementation of the financial liberalisation policy in 1980. In fact, the average M2/GDP ratio maintained after the liberalisation of interest rates is slightly lower than the average M2/GDP ratio, which was maintained before the liberalisation. 


\section{Stock Market Development in South Africa}

By the standards of emerging markets, the South African capital market is considered to be robust, liquid and well developed. Currently, South African securities are traded simultaneously in Johannesburg, London, New York, Frankfurt and Zurich. The Johannesburg Stock Exchange, which was formed in 1887, is currently one of the largest stock exchanges in the world by market capitalisation. It has also been a key role-player in the African Stock Exchanges Association since its formation in 1993. In 1990, the South African Futures Exchange (SAFEX), which trades in equity futures and a host of other futures contracts, was introduced. Since the 1990s, SAFEX has shown a significant growth trend. For example, in 1996 more than four million futures contracts, valued at US\$ 62 billion, were traded and, in 1999, SAFEX moved from being the $22^{\text {nd }}$ largest volume exchange to being the $18^{\text {th }}$ in the world. In 1996, the Bond Exchange of South Africa (BESA) was also licensed to trade as an exchange under the Financial Markets Control Act, 1989 (Act, No. 55 of 1989). During the same year of its registration, more than 430,000 stocks with a nominal value in excess of US\$ 704 billion changed hands. By 2001, the Bond exchange enjoyed an annual liquidity of more than 38 times the market capitalisation. This made it one of the most liquid emerging bond markets in the world (see South African Year Book, 2001).

For more than a century the securities stock industry was highly regulated through practices that were enforced by the JSE. The JSE was conventionally based on a strict 'single-capacity' rule. Member firms were either brokers or principals in securities trading (e.g. equities and bonds) but could not be both simultaneously. Membership was also limited to South African citizens with unlimited liability. Banks, as limited liability companies, were thus excluded from membership. However, in November 1995, structural changes were imposed on the JSE that resulted in a 'Big Bang' in 1996. In 1997, money market funds were introduced as a competitive alternative to bank deposits. These funds are managed as a sub-division of the unit trust industry and are today an important section of the market. However, the competition between banks and securities markets is not yet on a level playing field. This is mainly due to a wide arrange of restrictions on the issue of commercial paper and corporate bonds, which make it virtually impossible at present to use the securities market as a competitive alternative source for small business finance (see SA Financial Sector Forum, 1997; South Africa Yearbook, 1993; 1999; 2000; Felkana et al., 2001).

While the bank-based financial development in South Africa has consistently shown a mixed trend, the stock market development in South Africa has shown a more or less upward trend since the 1980s. For example, throughout the period from 1990 to 2005, the annual stock market capitalisation ratio recorded was over and above that of the 1980s. The stock market capitalisation ratio increased from 1.033 in 1989 to 1.466 in 1994, and to 1.6855 in 1995. The highest ratio was 1.828, which was recorded in 1996. Although the ratio subsided somewhat in 2002 to 1.234 , it later increased phenomenally to 1.7048 in 2004.

\section{LITERATURE REVIEW}

The debate regarding the relative roles of bank-based versus market-based financial systems in enhancing economic growth and development has been going on for decades now (see Levine 2003). The proponents of the bank-based system argue that a bank-based financial system is better than a market-based system because it can induce longer-term investment in the real sector. Specifically, banks can enhance domestic investment in a number of ways (see Ndikumane, 2005). By pooling financial savings, banks increase the amount of funds available for investment, i.e. investible funds. It is also argued that banks enhance investment by reducing liquidity risks and inducing higher quality and quantity of investment. Unlike the investment in the bank-based system, investment in the market-based system is considered to be too sensitive to the stock market prices and may not be sustainable in the long run (see Hoshi et al., 1990; Lee, 2001). Hence, the bank-based system can encourage productive investment as it is less affected by unstable financial markets. Even during recessions, the intimate relationship between banks and business can allow firms to continue with investment without pushing them into bankruptcy (Hoshi et al., 1990; Lee, 2001). Also, it is argued that industrial policies of the government can be carried out more easily in a bankbased system because it provides governments with more measures to intervene in the financial sector (i.e. interest rate regulation and credit control) than the market-based system (Pollin, 1995). 
However, the bank-based financial system has its own challenges. It is argued that a bank-based system is vulnerable to problems, such as inefficient capital allocation, along with the intimate relationship between banks and firms, and most of all, a higher debt-ratio. The moral hazard problem in the bank-based system is even worse. With the implicit government bailout, finance sometimes only does harm to the economy, making the system more vulnerable to financial crisis (Greenspan, 1999). The crisis in the East-Asian countries in the late 1990s is a case in point. Before the 1990s, some economists argued that the good performance of economies, such as Japan, as opposed to many market-based economies, was due to inefficiency in the market-based system, especially for longterm economic growth. However, with the emergence of the Asian crisis in the 1990s, this thinking was adversely challenged. As Greenspan (1999) puts it, if the capital market had been developed well in East Asia, the East Asia crisis would not have been that serious, since the capital market could have buffered the credit contraction in the banking sector.

The current debate however centres around the complementarity versus the substitutability between the two systems. The argument here is that since both banks and stock markets intermediate savings towards investment, they can be seen as either substitutes or as complements (see Naceur et al., 2007). Some recent studies have, however, shown that banks and stock markets are complementary rather than competitive systems (see Ndikumane, 2005). In other words, what is important is not whether a financial system is bank-based or stock market-based, but rather how developed and efficient the financial system is. In addition, some studies have shown that the role of the stock market in economic growth is dependent on a country's stage of development. In the early stages of development, banks play a predominant role in stimulating economic growth. However, as a country reaches higher levels of income, stock markets tend to play an increasing role (see also Demirguc-Kunt and Levine, 1999). This means that more-developed countries are expected to have relatively larger and more liquid stock markets, while less-developed countries are expected to be largely bank-based. Unfortunately, very few studies have attempted to empirically examine the relationship between bank-based financial system and stock market development. Some of the studies that have attempted to examine this linkage include those of Garcia (1986), Boyd and Smith (1996), Demirguc-Kunt and Levine (1996), Garcia and Liu (1999), Naceur et al. (2007) and Yartey (2008), amongst others. Boyd and Smith (1996), for example, suggest that banks and stock markets may behave as complements rather than substitutes. The empirical work done by Demirguc-Kunt and Levine (1996) also shows that the degree of stock market development is positively related to that of bank development. Similar results were obtained by Naceur et al. (2007) in the case of MENA countries. The authors, while examining the main determinants of stock market development, find that financial intermediaries and stock markets are complements rather than substitutes in the growth process. While examining the macroeconomic determinants of stock market development, Garcia and Liu (1999) also find that financial intermediary development has a positive impact on stock market development in a sample of Latin American and Asian countries. Contrary to the above studies, Garcia (1986) argues that central banks may generate a negative correlation between bank growth and stock market development. However, according to Yartey (2008), the relationship between the two systems is non-monotonic. At the early stages of its development banking sector development serves as a complement to the stock market development in financing investment. However, as the two systems develop, they begin to compete with each other as vehicles for financing investment.

\section{EMPIRICAL MODEL SPECIFICATION AND ESTIMATION TECHNIQUES}

\section{Empirical Model Specification}

In this study, the relationship between bank development and stock market development is examined by using a dynamic equation in which the stock market development, proxied by stock market capitalisation, is regressed on the bank development (proxied by DCP/GDP) and other regressors. The study uses the recently developed Autoregressive Distributed Lag (ARDL) - Bounds testing approach to examine the linkage between bank development and stock market development in South Africa. The ARDL modelling approach was originally introduced by Perasan and Shin (1999) and later extended by Perasan et al. (2001). The ARDL co-integration approach has numerous advantages in comparison to other co-integration methods. Unlike other co-integration techniques, the ARDL does not impose a restrictive assumption that all the variables under study must be integrated of the same order. In other words, the ARDL approach can be applied regardless of whether the underlying regressors are integrated of order one $[\mathrm{I}(1)]$, order zero $[\mathrm{I}(0)]$ or fractionally integrated. Secondly, while other co- 
integration techniques are sensitive to the size of the sample, the ARDL test is suitable even if the sample size is small. Third, the ARDL technique generally provides unbiased estimates of the long-run model and valid t-statistics even when some of the regressors are endogenous (see also Harris and Sollis, 2003). The ARDL model used in this study can be expressed as follows:

$$
\begin{aligned}
& \Delta \operatorname{InSCAP} P_{t}=\alpha_{0}+\sum_{i=1}^{n} \alpha_{1 i} \Delta \operatorname{InSCAP} P_{t-i}+\sum_{i=0}^{n} \alpha_{2 i} \Delta \operatorname{InDCP} / G D P_{t-i}+\sum_{i=0}^{n} \alpha_{3 i} \Delta \operatorname{Iny} / N_{t-i}+\sum_{i=0}^{n} \alpha_{4 i} \Delta \operatorname{InS} / Y_{t-i} \\
& +\sum_{i=0}^{n} \alpha_{5 i} \Delta \operatorname{In} \operatorname{INF}_{t-i}+\alpha_{6} \operatorname{InSCAP} P_{t-1}+\alpha_{7} \operatorname{InDCP} / G D P_{t-1}++\alpha_{8} \operatorname{Iny} / N_{t-1}+\alpha_{9} \operatorname{In} S / Y_{t-1}+\alpha_{10} \operatorname{In} \operatorname{INF}_{t-1} \\
& +\mu_{t}
\end{aligned}
$$

where:

InCAP $=\log$ of stock market capitalisation as a ratio of GDP

$\mathrm{InDCP} / \mathrm{GDP}=\log$ of domestic credit to the private sector as a ratio of GDP

Iny $/ \mathrm{N}=\log$ of per capita real GDP

In $\mathrm{S} / \mathrm{Y}=\log$ of Savings ratio as a ratio of GDP

InINF $=\log$ of inflation

$\mu_{\mathrm{t}}=$ white noise error term

$\Delta=$ first difference operator

The rationale for including other variables other than bank development in the stock market function is based on the following theoretical arguments: The inclusion of real income is aimed at examining the relationship between real income and stock market development. Studies have shown that there is a strong correlation between the real income and the size of the stock market. According to the demand-following phenomenon, the lack of financial growth is a manifestation of a lack of demand for financial services. As the real side of the economy develops, its demands for various new financial services inevitably increase, and these are met rather passively from the financial side (see Patrick, 1966). The coefficient of the real GDP is therefore expected to be positive and statistically significant. The savings rate is another important determinant of stock market development. As in the case of banks, stock markets are expected to intermediate savings towards investment projects. The larger the saving rate, the higher the flow of capital to stock markets (see Naceur et al., 2007). The coefficient of the saving rate is therefore expected to be positive and statistically significant. Inflation has been included in the model as a measure of macroeconomic stability. The coefficient of this variable is expected to be negative and statistically significant because the higher the inflation rate the lower will be the incentive to investment in the stock market.

\section{Data Source and Definition of Variables}

\section{Data Sources}

Annual time series data, which cover the 1969 to 2008 period, are utilised in this study. The data used in this study were largely obtained from the South African Reserve Bank annual reports and quarterly bulletins. In addition, different volumes of the International Financial Statistics (IFS) Yearbook, published by the International Monetary Fund, and World Development Indicators were used to supplement the local data.

\section{Definition of Variables}

- Domestic credit to the private sector (DCP/GDP) is calculated as the ratio of total domestic credit to the private sector to GDP.

- $\quad$ The stock market capitalisation variable (STK) is calculated by dividing the value of listed companies (market capitalisation) by GDP.

- $\quad$ Real GDP per capita is computed as follows:

- Real GDP per capita $(\mathrm{y} / \mathrm{N})=$ Real GDP $(\mathrm{y}) /$ Total Population $(\mathrm{N})$. 
- $\quad$ Savings ratio $(\mathrm{S} / \mathrm{Y})$ is calculated as gross domestic savings/GDP.

- $\quad$ Rate of Inflation rate (INF) is calculated from the consumer price index (CPI).

\section{Empirical Analysis}

\section{Stationarity Tests}

Although the ARDL modelling approach does not require unit root tests, it is important to conduct the unit root test in order to ensure that no variable is integrated of order $2[\mathrm{I}(2)]$ or higher. This is critical because the ARDL procedure assumes that all variables are either $\mathrm{I}(0)$ or $\mathrm{I}(1)$. If a variable is found to be $\mathrm{I}(2)$, then the computed Fstatistics, as produced by Pesaran et al (2001), can no longer be valid. The results of the stationarity tests at level (not presented here) show that all the variables in the stock market model are non-stationary at levels. Having found that the variables are not stationary at levels, the next step is to difference the variables once in order to perform stationarity tests on differenced variables. The results of the stationarity tests on differenced variables are presented in Tables 1 and 2.

Table 1: Stationarity Tests of Variables on first Difference - Phillips-Perron (PP) Test

\begin{tabular}{|l|c|c|}
\hline \multicolumn{1}{|c|}{ Variable } & No Trend & \multicolumn{1}{c|}{ Trend } \\
\hline \multicolumn{1}{|c|}{ Phillips-Perron (PP) } & $-5.54889 * * *$ \\
\hline DLy/N & $-5.501179 * * *$ & $-6.179666 * * *$ \\
\hline DLSCAP & $-6.26520 * * *$ & $-9.696399 * * *$ \\
\hline DDCP/GDP & $-9.569110 * * *$ & $-7.154969 * * *$ \\
\hline DLINF & $-6.171235 * * *$ & $-6.42924 * * *$ \\
\hline DLS/Y & $-6.55047 * * *$ & \\
\hline
\end{tabular}

Note: 1) The truncation lag for the PP tests is based on Newey and West (1987) bandwidth. 2) *** denotes $1 \%$ level of significance.

Table 2: Stationarity Tests of Variables on first Difference -Ng -Perron TEST

\begin{tabular}{|l|c|c|c|c|}
\hline \multicolumn{1}{|c|}{ Variable } & MZa & MZt Ng-Perron Test & MSB & MPT \\
\hline DLy/N & -16.6091 & -2.84720 & 0.17142 & 1.60206 \\
\hline DLSCAP & -15.0072 & -2.71665 & 0.18102 & 1.71763 \\
\hline DDCP/GDP & -13.5872 & -2.59773 & 0.19119 & 1.83651 \\
\hline DLINF & -27.2227 & -3.51796 & 0.12923 & 1.43491 \\
\hline DLS/Y & -19.9082 & -3.15489 & 0.15847 & 1.23107 \\
\hline Critical Values & -13.8000 & -2.58000 & 0.17400 & 1.78000 \\
\hline $1 \%$ & -8.10000 & -1.98000 & 0.23300 & 3.17000 \\
\hline $5 \%$ & -5.70000 & -1.62000 & 0.27500 & 4.45000 \\
\hline $10 \%$
\end{tabular}

The results reported in Tables 1 and 2 show that after differencing the variables once, all the variables were confirmed to be stationary. The Phillips-Perron and Ng-Perron tests applied to the first difference of the data series reject the null hypothesis of non-stationarity for all the variables used in this study. It is, therefore, concluded that all the variables are integrated of order one.

\section{Bounds F-test for Co-integration}

The ARDL-Bounds testing procedure involves two steps. In the first step, the order of lags on the first differenced variables in the stock market development equation is obtained from the unrestricted models by using the Akaike Information Criterion (AIC) and the Schwartz Bayesian Criterion (SBC). The results of the above tests (not reported here) show that the optimal lag for the stock market development function is lag 2. Having established the optimal lag length the next step is to apply the bounds F-test in order to establish the long-run relationship between the variables included in the equation. The results of the bounds test are reported in Table 3. 
Table 3: ARDL Bounds Test for Co-integration Analysis

\begin{tabular}{|l|c|c|}
\hline Computed F- Statistic: 5.808 & Lower & Upper \\
\hline Critical Bounds (1\%) & 3.74 & 5.06 \\
Critical Bounds (5\%) & 2.86 & 4.01 \\
\hline
\end{tabular}

Critical values are taken from Table C1(iii) of Pesaran et al (2001): Unrestricted intercept and no trend in the model.

The results of the Bounds test presented in Table 3 show that the computed F-statistic (5.808) exceeds the upper bound critical value (5.06) at the $1 \%$ level of significance. This indicates that there is a stable long-run relationship between the stock market development variable and its determinants, namely domestic credit to the private sector (DCP/GDP), real per capita income, savings (S/Y) and inflation.

\section{Unrestricted Error-Correction Model (UECM)}

Having confirmed the existence of a stable long-run relationship, the next step is to derive the long-run and short-run coefficients of the explanatory variables in the stock market model by using the simplest UECM. Table 4 gives the results of the simplest UECM based on Henry's general-to-specific approach (1991).

Table 4: The Estimated UECM

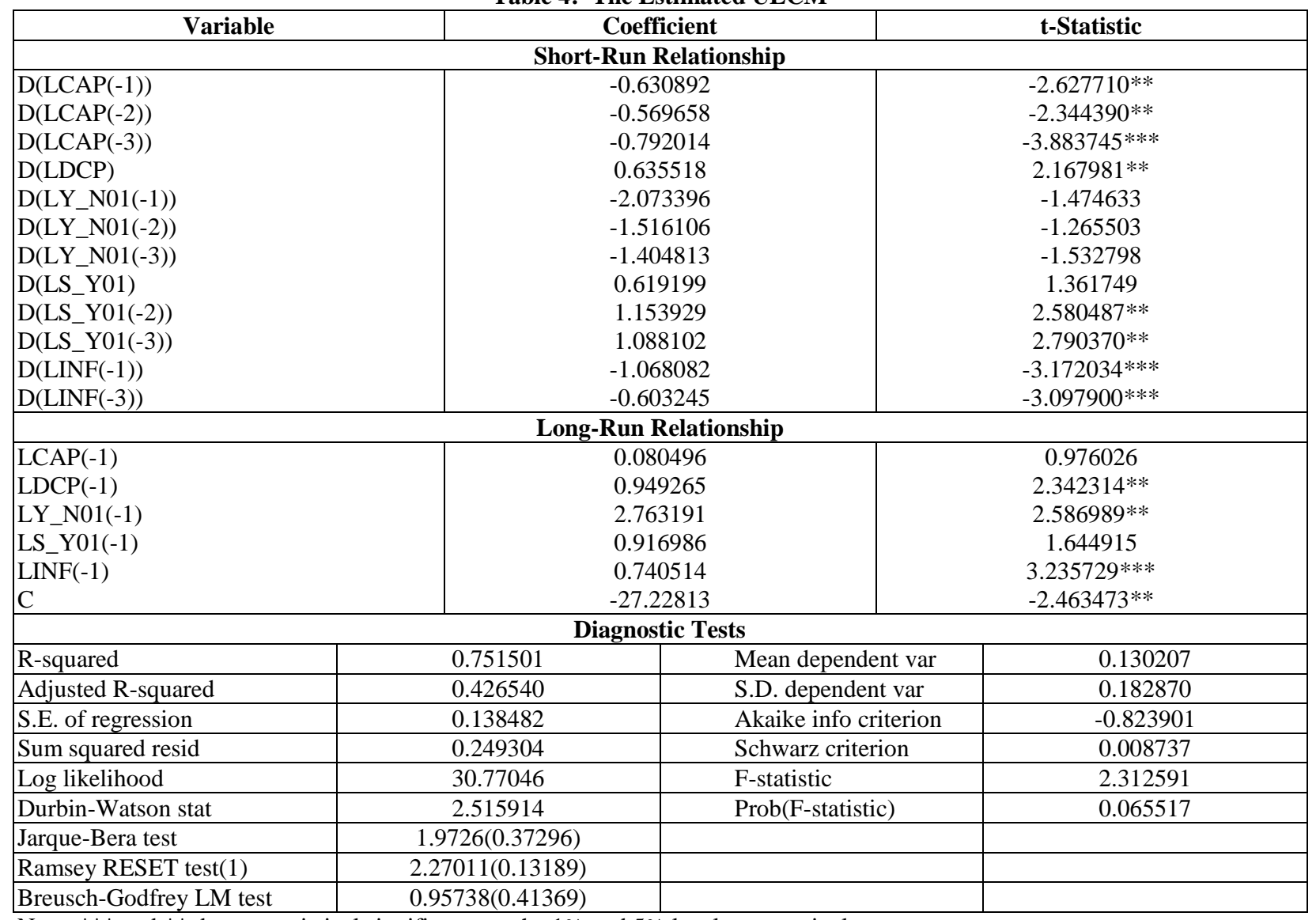

Note: $* * *$ and $* *$ denote statistical significance at the $1 \%$ and $5 \%$ levels, respectively

The results reported in Table 4 show that there is a positive relationship between bank-based financial development and stock market development in South Africa. The results apply both in the short run and also in the long run. The short-run positive relationship is supported by the coefficient of the differenced domestic credit to the private sector variable, which is found to be positive and statistically significant. The long-run relationship, on the 
other hand, is supported by the coefficient of the lagged level of the domestic credit to the private sector, which is positive and statistically significant. Specifically, the results show that the long-run elasticity of the domestic credit to the private sector is 11.970 . Other results show that in the short run the stock market development in South Africa is positively determined by the level of savings, but negatively affected by the level of inflation, as well as the lagged values of the stock market development. However, in the long run the stock market development is largely determined by real income and inflation rate. The long-run elasticities of income and inflation are 37.32 and 9.19 , respectively.

Since the stability of the stock market function is vital in a study of this nature, it is important to test whether the estimated stock market equation has shifted over time. For this purpose, the CUSUM and CUSUM Square class of tests have been used. As can be seen from Figures 1 and 2, the CUSUM and CUSUM Square tests for stability indicate that the parameters were stable during the sample period.

Figure 1: Plot of CUSUM stability Test for Stock Market Development

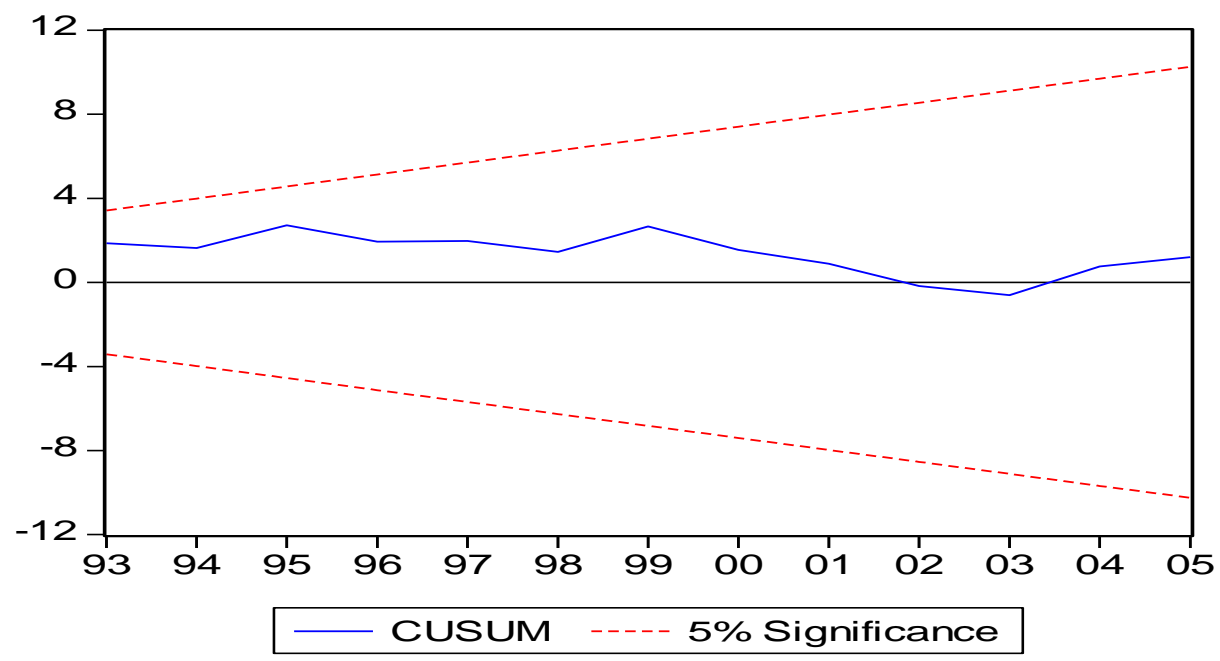

Figures 2: Plot of CUSUM of Squares Stability Test for Stock Market Development

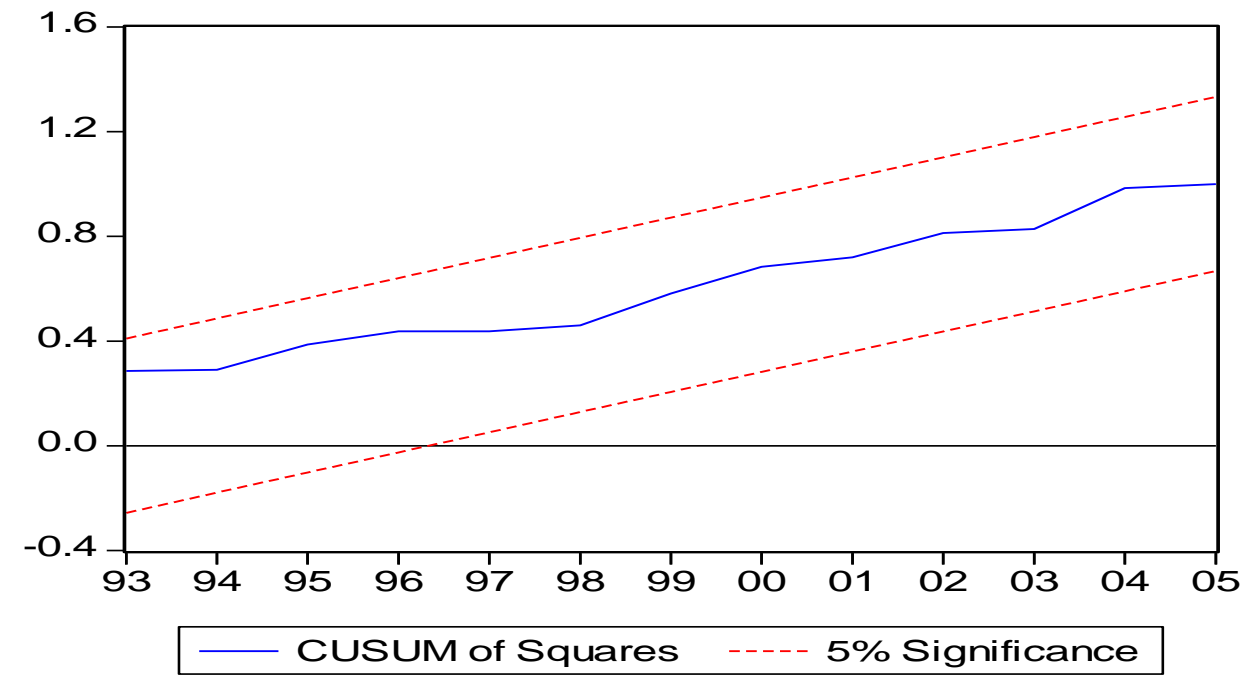




\section{CONCLUSION}

This study examines the relationship between bank-based financial development and stock market development in South Africa using the newly developed ARDL-bounds testing approach. Specifically, the study aims to examine whether the services rendered by banks and stock markets are positively or negatively related. Previous studies on this subject have over-relied on cross-country data, which rarely address country-specific issues. Moreover, some of these studies have used either the residual-based countegration test proposed by Engle-Granger (1988) or the maximum likelihood test proposed by Johansen (1988) and Johansen and Juselius (1990) to examine the long relationship between stock markets and bank development. However, these methods have been found to be inappropriate when the sample size is small. The empirical results of this study show that there is a distinct positive relationship between bank development and stock market development in South Africa. The results apply, irrespective of whether the stock market development model is estimated in the short run or in the long run. The short-run positive relationship is supported by the coefficient of the first difference of the bank development variable in the stock market development function, which is positive and statistically significant. The long-run relationship, on the other hand, is supported by the first lag of the bank development variable in the stock market development function, which is also positive and statistically significant. This finding is consistent with those of Demirguc-Kunt and Levine (1996), Boyd and Smith (1996) and Garcia and Liu (1999), among others. Other results show that in the short run, stock market development in South Africa is positively determined by the level of savings, but negatively affected by the rate of inflation and the lagged values of the stock market development. However, in the long run, the stock market is largely determined by real income and the inflation rate.

\section{AUTHOR INFORMATION}

Prof Nicholas M Odhiambo holds a PhD (Economics) degree from Stellenbosch University (South Africa), and a Masters degree in Economics from the University of Dar-es-salaam (Tanzania), both of which were sponsored by the African Economic Research Consortium (AERC). Prof Odhiambo's research profile is broad, rich and multifaceted. During the past eight years, Prof Odhiambo has published more than 39 articles in 24 local and international journals. Prof Odhiambo is listed in a number of international bibliographies and databases. He has also served on the Reviewers' Boards of a number of journals, and is currently a member of the Editorial Board of four prominent journals.

\section{REFERENCES}

1. Boyd, J. and Smith, B.D. (1996), "The Coevolution of the Real and Financial Sectors in the Growth Process", World Bank Economic Review 10: 371-396.

2. Demirgüç-Kunt, A. and Levine, R.B(1999) "Bank-based and Market-Based Financial Systems: CrossCountry Comparisons," The World Bank, Policy Research Working Paper 2143.

3. Demirguc-Kunt, A. and Levine, R. (1996) "Stock Markets, Corporate Finance and Economic Growth: An Overview”, World Bank Economic Review 10 (May): 223-239.

4. Engle, R.F. and Granger, C.J. (1987), "Co-integration and Error-correction - Representation, Estimation and Testing", Econometrica 55 (2): 251-78.

5. Falkena, H.B., Fourie, L.J. and Kok, W.J. (1995), The South African Financial System, Half Way House, Southern Book Publishers.

6. Falkena, H.B., Bamber, R., Llewellyn, D. and Store, T. (2001), Financial Regulation in South Africa, Published by SA Financial Sector Forum, Second Edition (March).

7. Garcia, V.F. (1986). Critical Enquiry into Argentine Economic History 1946-1970. Garland Publishing Co., New York.

8. Garcia, F. V. and Liu, L. (1999), “Macroeconomic Determinants of Stock Market Development,” Journal of Applied Economics, Vol. 2 (1), pp. 29-59.

9. Greenspan, Alan (1999), "Lessons from Global Crises, Before the World Bank and the IMF, Program of Seminars, Washington DC (September).

10. Harris, R. and Sollis, R. (2003), Applied Time Series Modelling and Forecasting, John Wiley, New York.

11. Hendry, D.F. and Ericsson, N. (1991), "Modelling the Demand for Narrow Money in the United Kingdom and the United States", European Economic Review 35:833-86. 
12. Hoshi, T., Kashyap, A. and Scharfstein, D. (1990), "The Role of Banks in Reducing the Costs of Financial Distress in Japan”, Journal of Financial Economics 27: 67 - 88.

13. Johansen, S. and Juselius, K. (1990), "Maximum Likelihood Estimation and Inference on Co-integration with Applications to the Demand for Money", Oxford Bulletin of Economics and Statistics 52:169-210.

14. Johansen, S. (1988), "Statistical Analysis of Co-integration Vectors", Journal of Economic Dynamics and Control 12: 231-54.

15. Lee, Kongkook (2001) "Note on Study of the Changes of Financial System" Ref. 00.12-Department of Economics, University of Massachusetts.

16. Levine, R. (2003), "Stock Markets Liquidity and Economic Growth: Theory and Evidence", in Luigi Paganetto and Edmond S. Phelps (eds), Finance, Research, Education and Growth, Palgrave Macmillan, New York.

17. Narayan, P.K. and Smyth, R. (2005), "Electricity Consumption, Employment and Real Income in Australia: Evidence from Multivariate Granger Causality Tests", Energy Policy 33: 1109-1116.

18. Naceur, B.S., Ghazouani, S. and Omran, M. (2007), "The Determinants of Stock Market Development in the Middle-Eastern and Northern African Region”, Managerial Finance 33:477-489.

19. Ndikumana, L. (2005), "Financial Development, Financial Structure, and Domestic Investment: International Evidence", Journal of International Money and Finance 24: 651-673.

20. Newey, W.K., West, K.D.(1987), “A Simple, Positive Semi-Definite, Heteroskedasticity and Autocorrelation Consistent Covariance Matrix", Econometrica 55: 703-8.

21. Patrick, H.T. (1966), "Financial Development and Economic Growth in Underdeveloped Countries", Economic Development and Cultural Change 14 (1): 174-189.

22. Pesaran, M.H. and Shin, Y. (1999), “An Autoregressive Distributed Lag Modelling Approach to Cointegration Analysis", in Econometrics and Economic Theory in the $20^{\text {th }}$ Century: The Ragnar Frisch Centennial Symposium, eds. Storm, S., Cambridge University Press, Chapter 11, pp.1-31.

23. Pesaran, M.H., Shin, Y. and Smith, R. (2001), "Bound Testing Approaches to the Analysis of Level Relationship, Journal of Applied Econometrics 16: 174-89.

24. Pollin, Robert (1995), "Financial Structures and Egalitarian Economic Policy", New Left Review 214, November - December, pp. 26-61.

25. SA Financial Sector Forum, Annual Bulletin, Various Issues.

26. South Africa Official Year Book, Various issues.

27. Yartey, CA (2008), “The Determinants of Stock Market Development in Emerging Economies: Is South Africa Different?", IMF Working Paper No. WP/08/32. 